\title{
Development of Interactive E-Module on The Periodic System Materials as an Online Learning Media
}

\author{
Syahrul Wahyu Rahmatsyahㄹ, Kusumawati Dwiningsih ${ }^{1 *}$ \\ ${ }^{1}$ Chemistry Department, Faculty of Mathematics and Natural Science, Universitas Negeri Surabaya, Surabaya, Indonesia.
}

DOI: $\underline{10.29303 / \text { jppipa.v7i2.582 }}$

\section{Article Info}

Received: January $15^{\text {th }}, 2021$

Revised: April 15th, 2021

Accepted: April 19th, 2021

\begin{abstract}
The purpose of this research is to determine the feasibility, effectiveness, and practicality of learning media in the form of an interactive e-module with the research method used is Research and Development (R\&D) with a 4D development model (Define, Design, Develop, and Disseminate) which is modified into 3D. The instruments used consisted of review sheets, validation, student response questionnaires, tests (pretest and posttest). The data were obtained based on the results of interviews with chemistry teachers and giving questionnaires to students. The results of the validation of this device got the score of $90 \%$ for content criteria, $93 \%$ for presentation criteria, $84 \%$ for language criteria, and $100 \%$ for graphic criteria are very feasible to use. The practicality of the e-module is known from the results of the responses of students with an average score of more than $81 \%$ which can be categorized as highly responding. The interactive e-module is also said to be very effective by analyzing learning outcomes using the $t$-test with a significance value of $5 \%$. Therefore, the use of interactive e-modules on the element periodic system material can be used as learning media in carrying out online learning activities
\end{abstract}

Keywords: interactive e-module; elemental periodic system; online learning.

Citation: Rahmatsyah, S., \& Dwiningsih, K. (2021). Development of Interactive E-Module on The Periodic System Materials as an Online Learning Media. Jurnal Penelitian Pendidikan IPA, 7(2), 255-261. doi:https://doi.org/10.29303/jppipa.v7i2.582

\section{Introduction}

Education is one of the ways to advance and educate humans, especially the Indonesian nation. In the implementation of education, the use of a certain curriculum determines the direction in educational progress. One of them is the use of the 2013 curriculum which is oriented towards improving skills, attitudes, and knowledge by following per under Article 35 of Law no. 20 of 2003 which contains graduate competencies is the qualification of graduate abilities which includes attitudes, knowledge, and skills by following per under agreed national standards. So that character values can be integrated into learning (Sholeh, 2017).

Chemistry is a science that is acquired and developed through experimenting and seeking answers to questions about what, why, and how natural phenomena can occur. Therefore, it is necessary to master the concepts and materials and apply chemistry in everyday life ( Rorita \& Saida, 2018).

The year 2020 was shocked by the outbreak of the coronavirus (COVID-19) which caused chaos around the world. The COVID-19 pandemic has also had a negative impact on the Indonesian state, starting from the social life of the community, the economy, to education. This is an external factor that affects teaching and learning activities (Strielkowski, 2020). Physical limitations make all activities limited and forced online learning. Online learning is a form of teaching and learning activities carried out remotely using the internet which functions to connect students with learning resources (Kuntarto, 2017). The media used in online learning are very diverse, some use virtual classes such as Google classroom, Edmodo, to Whatsapp Group. There are also 
those through video conferencing such as zoom, google meet, Microsoft Teams, and others (Kind, 2015). However, time constraints and network quality make online learning less effective than face-to-face learning (Abidah et al., 2020).

SMAN 15 Surabaya is one of the schools in Surabaya that implements online learning through Microsoft Teams. Some students at SMAN 15 Surabaya have difficulty understanding chemical materials, one of which is the periodic system of elements. The material of the periodic system of elements cannot be studied 2-3 times face to face, because there is a complex understanding, namely the configuration of electrons and quantum numbers (Damayanti \& Dwiningsih, 2017). Therefore, the use of e-module learning media is the right solution to solve this problem.

An electronic module (e-module) is a set of nonprinted digital learning media that are arranged systematically and can be used independently by students to solve problems in their way (Fausih \& Danang, 2015). E-modules have the advantages of being practical, long durability, and lower production costs than print modules in general (Ramadhan \& Linda, 2020). E-modules have various types, one of which is interactive. The advantage of the interactive e-module is that it is interactive, makes it easy to navigate, and displays images, audio, video animation and is equipped with tests or quizzes that provide reciprocal effects automatically (Suarsana \& Mahayukti, 2013). The interactive e-module can be used as a learning medium in online learning activities. On an offline e-module basis, the E-module does not have to use an internet quota to access it, where students can download the emodule and then operate it on a personal PC or laptop that can be accessed anytime and anywhere.

Based on the above background, it is necessary to conduct research with the title of interactive e-module development on the elemental periodic system material as an online learning medium.

\section{Method}

The type of research used is Research and Development (R\&D). The R\&D method is a process for developing a new product or perfecting an existing product, in which all its activities can be justified (Juilando, 2019). The development model in research uses a 4D model that becomes 3D because the research objective is only up to the interactive e-module trial stage that is developed (Syarmadi, \& Izzati, 2020). The 3D model itself consists of 3 stages, namely define, design, and develop (Thiagarajan, 1976).

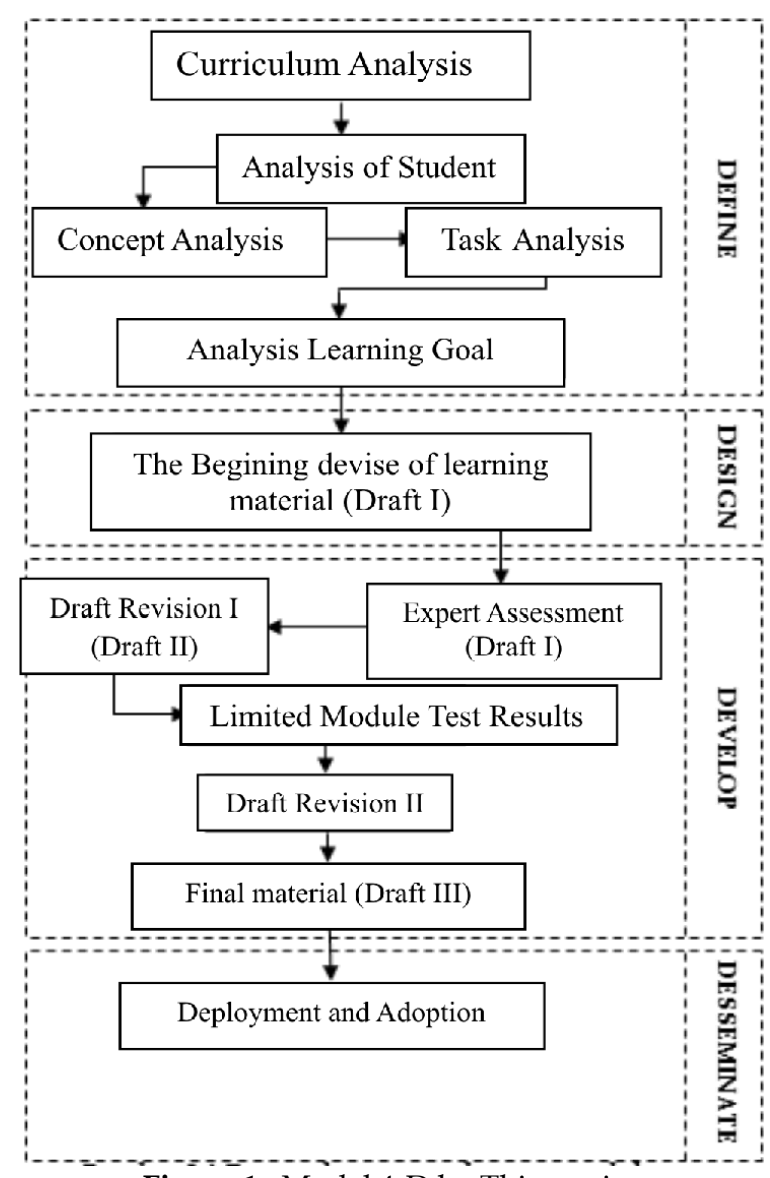

Figure 1. Model 4-D by Thiagarajan

At the define stage, 5 main steps are taken, including: (1) front-end analysis, to analyze the problems that underlie the development of interactive emodules; (2) student analysis (learner analysis), to analyze the characteristics of students such as learning abilities and skills; (3) concept analysis, by compiling the material design of the periodic system of elements; (4) task analysis, determining the learning indicators used in accordance with applicable basic competencies; (5) analysis of learning objectives (specifying instructional objectives), to summarize the results of concept analysis and analysis of tasks used to compile tests and design emodules (Thiagarajan, 1976).

The second stage designs. Activities undertaken are the preparation of tests, media selection, format selection, and initial design. The first step begins with the preparation of tests based on the learning objectives and analysis of students. Then the selection of learning media in accordance with the defined stage, namely the interactive e-module on the element periodic system material, then selecting the e-module format by designing or designing a storyboard for the product to be developed (Izzati, 2017).

The last stage is development. This stage aims to produce a product in the form of an interactive e-module that is valid and suitable for use as a learning medium 
through study, validation, and development trials. The validation process begins with creating a validation instrument containing content and construct validation (Izzati, 2017). The validation sheet is used to determine the value of the product to be developed according to the Likert scale presented in Table 1.

Tabel 1. Likert scale

\begin{tabular}{lc}
\hline Statement & Score \\
\hline Invalid & 1 \\
Less valid & 2 \\
Quite valid & 3 \\
Valid & 4 \\
Very valid & 5 \\
\hline
\end{tabular}

(Riduwan, 2013)

The data obtained from the validator is ordinal. The ordinal data is qualitative data that will be assessed by giving a score to the categories for each item (Izzati, 2017). Further analysis needs data with an interval scale, where ordinal data must be transformed first (Waryanto \& Millafati, 2006). Data were analyzed using the Method of Summated Ratings (MSR) to obtain a percentage of validity with Equation 1 :

$$
(\%) \text { Validity }=\frac{\text { total score }}{\text { Max score }} \times 100 \%
$$

The percentage results obtained are interpreted into the score criteria presented in Table 2.

Table 2. Percentage of Validity Criteria

\begin{tabular}{ll}
\hline Percentage (\%) & Score \\
\hline $0-20$ & Invalid \\
$21-40$ & Less valid \\
$41-60$ & Quite valid \\
$61-80$ & Valid \\
$81-100$ & Very Valid \\
\hline
\end{tabular}

(Riduwan, 2013)

Based on these criteria, the e-module is said to be valid if all aspects of the percentage are $\geq 61 \%$ (Riduwan, 2013).

\section{Result and Discussion}

The research produces an interactive e-module in which there is a learning component consisting of material for each sub-chapter, learning videos, summaries, and practice questions contained at the end of the material for each sub-chapter.

\section{Defining}

The definition stage consists of 5 main aspects, namely front-end analysis, student analysis, concept analysis, task analysis, and learning objectives analysis. Starting from the font-end analysis, where online learning activities, which are generally through virtual classes and video conferences, have many obstacles, one of which is an unstable connection. Analysis of students found that some students felt bored and monotonous when online learning took place through video conferences. So that the interactive e-module development was chosen which could shape the characteristics of students to be creative and independent in learning. The next stage is analyzing the concepts, assignments, and learning objectives. In this case, the element periodic system material was selected based on the essential Basic competence (KD) of the 2013 revision of the 2020 curriculum which consists of 3 subchapters, including: (1) the history of the periodic table development, (2) electron configuration, (3) quantum numbers. The learning objectives and learning indicators are adjusted to the selected basic competence, namely basic competence 3.2 with material explaining the electron configuration and the pattern of the outer electron configuration for each group in the periodic table (Kemendikbud, 2020).

\section{Design}

The interactive e-module developed is in exe format which means it can only be accessed via Personal Computer (PC) or Laptop. Students don't need the internet to operate it, they only need downloading an emodule file of $100 \mathrm{MB}$. Files will be sent via Whatsapp group or Microsoft Teams.

E-modules are typed using the Microsoft Word 2019 application. E-modules are prepared based on the component components of the module described in the (Depdiknas, 2016). The main part of the e-module consists of mapping basic competencies, instructions for using the e-module, the content of the material, video lessons, summaries, practice questions, and bibliography. Cover design and template for each page, designed using the Corel Draw 2020 application.

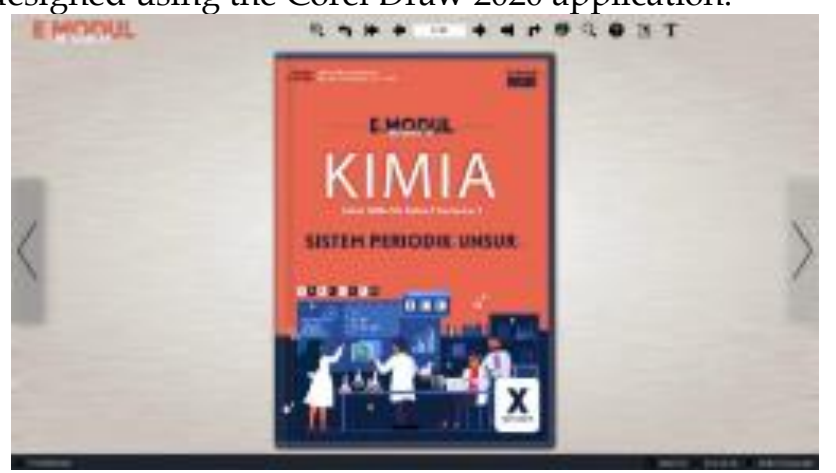

Figure 2. Cover e-module

Figure 2 displays the initial view after opening the interactive e-module file, students are immediately presented with an e-module cover. Then, students are also provided the navigation buttons on the interactive e-module page. The navigation buttons consist of zoom in, zoom out, previous page, next page, print, search, help, and select text. 


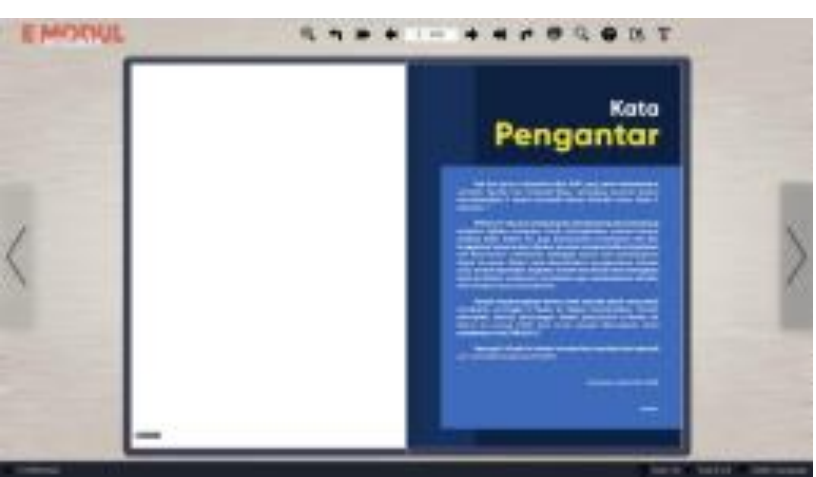

Figure 3. Preface

After opening the cover, students will be presented with an opening voice "Welcome to the Class 10 Interactive Chemistry e-module" along with the introduction as shown in Figure 3.

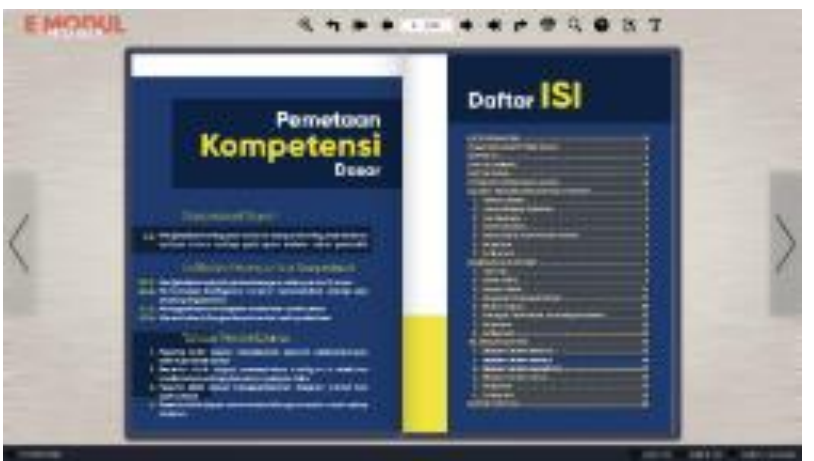

Figure 4. Basic competence mapping and table of contents

Figure 4 displays a mapping of basic competence that contains basic competencies, indicators of competence achievement, and learning objectives. On the next page, a table of content that can be clicked to go to the target page is displayed.

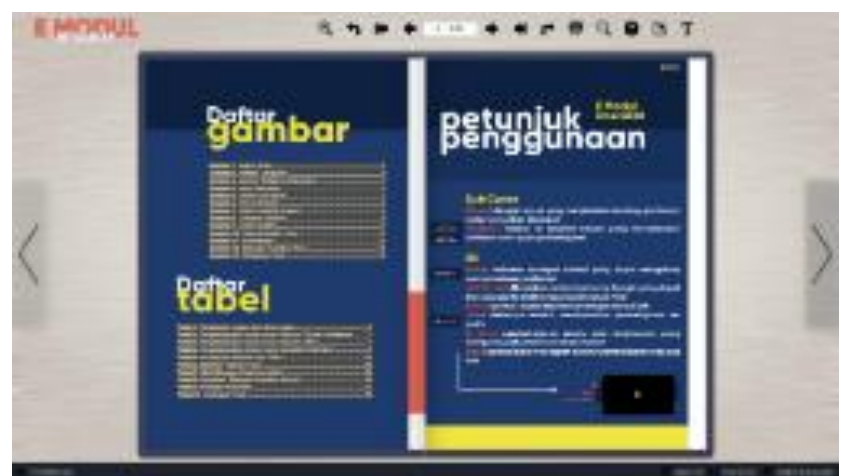

Figure 5. Instructions for using the e-module

Figure 5 displays a list of figures and a list of tables that can be clicked on to the table or image that we are going to target. The next page displays instructions for using the e-module, here students will be directed on how to operate the e-module because each component in it can be clicked and gives reciprocal effects such as buttons, images, and learning videos.

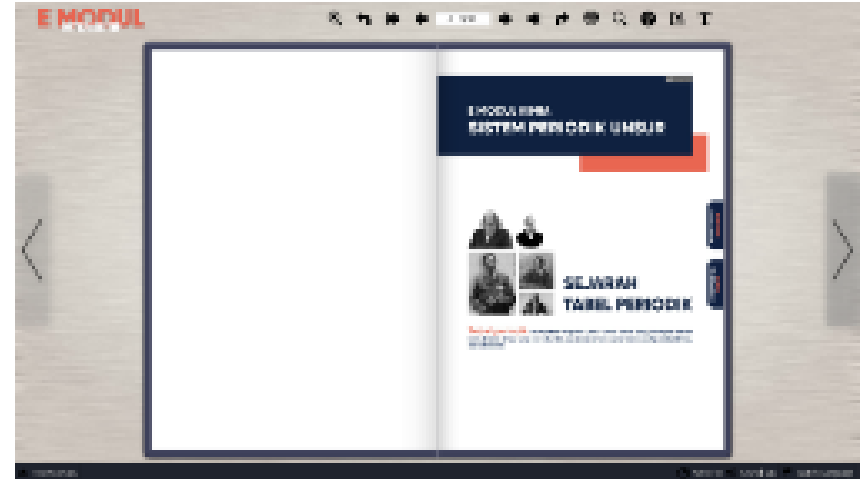

Figure 6. Cover of each section

Figure 6 shows the cover of the subsections contained in each of its sections, starting from the historical development of the periodic table, electron configuration, and quantum numbers. Students listen to the audio related to the material description automatically. The indicator button and learning objectives can also be clicked. To display the indicators and learning objectives of the material.

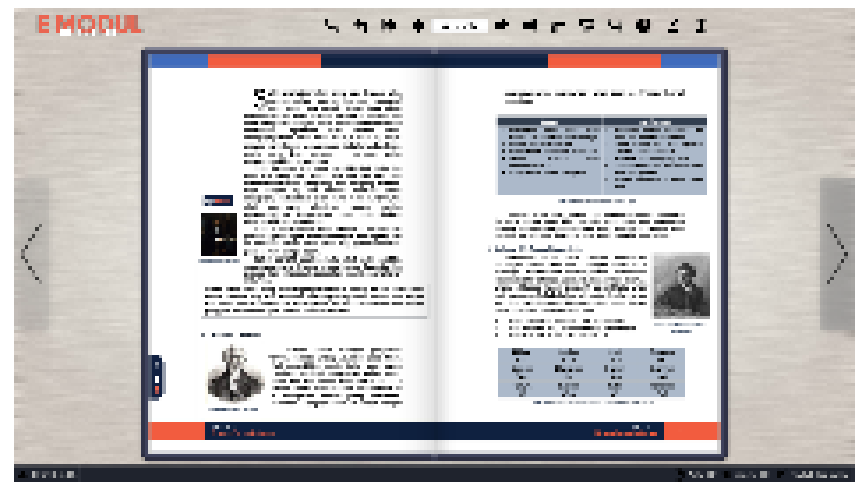

Figure 7. Contents

Figure 7 displays the content of the material in detail, accompanied by an image that can be enlarged by clicking. Not only that, some materials also contain audio which contains a brief explanation.

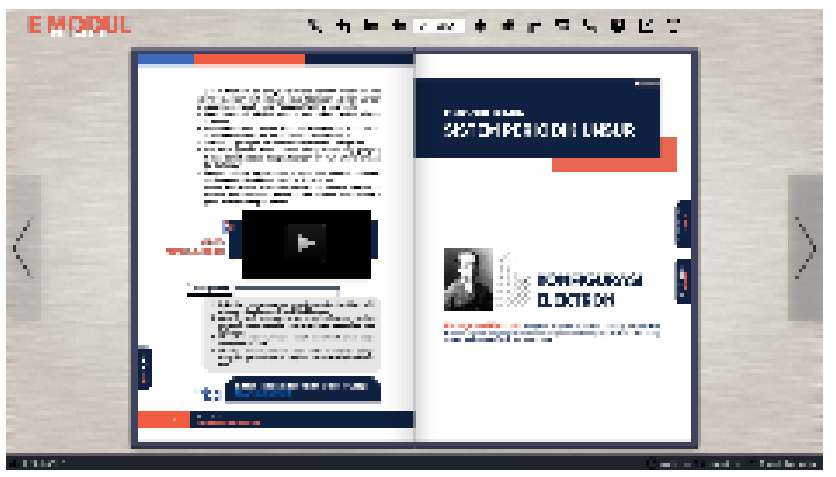

Figure 8. Video learning

Figure 8 shows various components ranging from instructional videos in thumbnail form, which means that they can be enlarged to the size of the screen. Then there is a summary of the material presented at the end of each material. The last component is a practice 
question. Exercise questions are given to hone the abilities of students which are packaged in the form of a link that is connected to google form. The three components are on the last page of each sub-chapter.

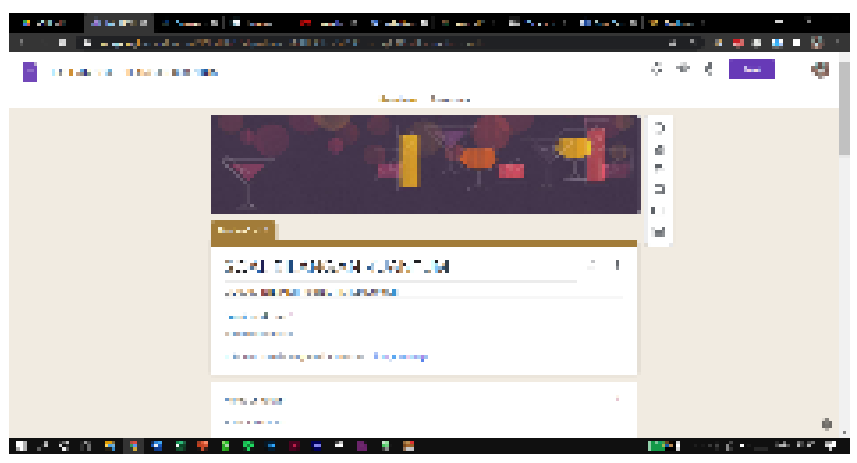

Figure 9. Practice questions

Figure 9 displays the practice questions in the form of a Google form that you can do and immediately get feedback in the form of a score. Students will be given 10 multiple choice questions for each sub-chapter, which are in accordance with the cognitive domain, namely $\mathrm{C} 3$ and C4 with unlimited time (BNSP, 2010).

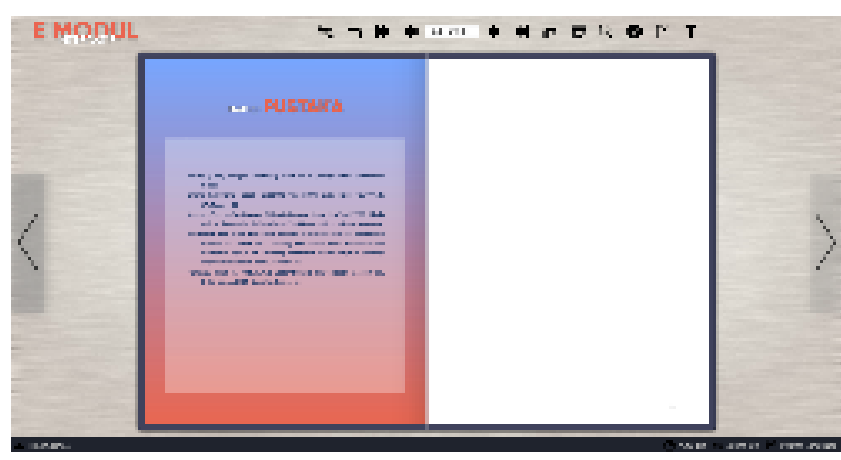

Figure 10. Bibliography

Figure 10. displays a bibliography of the interactive chemistry e-module

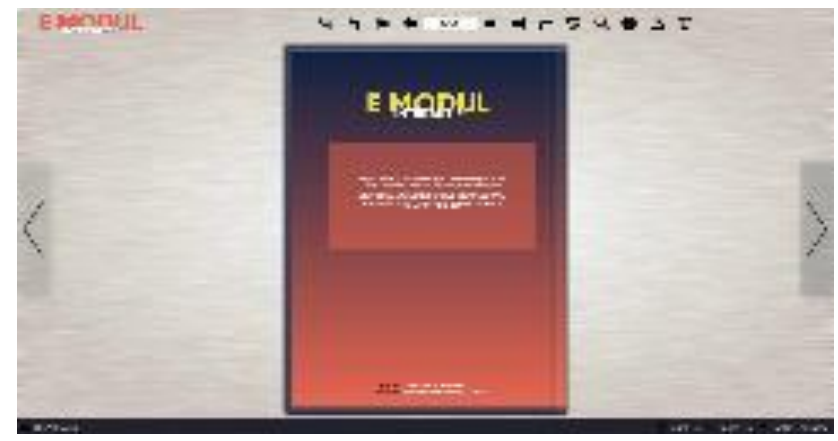

Figure 11. Back Cover

Figure 11. is the last page of this e-module, where there is an e-module back cover that contains a brief description of this interactive e-module.

Develop

The development stage begins with a product review of the supervisor first. Then proceed with creating a validation instrument to determine the validity of this e-module. After the validation instrument was prepared, then an assessment would be carried out by the validator, namely 2 lecturers from the chemistry department and 1 chemistry teacher at SMAN 15 Surabaya. The validation sheet contains content, presentation, language, and graphic criteria. The final data obtained from the three validators are presented in table 3.

Table 3. Data Validation Results

\begin{tabular}{ccc}
\hline Rating Criteria & $\begin{array}{c}\text { Average } \\
\text { Percentage (\%) }\end{array}$ & Category \\
\hline Contents & 90 & Very Valid \\
Presentation & 93 & Very Valid \\
Language & 84 & Very Valid \\
Graphics & 100 & Very Valid \\
\hline
\end{tabular}

The data from Table 3 are broken down according to the categories of the validation instrument, starting from the content criteria which get a percentage of $90 \%$, the presentation criteria of $93 \%$, the linguistic criteria with the lowest score of $83 \%$, and the criteria for the graphics with the highest score of $100 \%$. From these data, it can be concluded that this learning media is valid with a score $\geq$ of 61 for each criterion and the suitability of the material with competence standards and basic competence(Herawati \& Muhtadi, 2018).

The next stage is to conduct trials on students to know the practicality and effectiveness of this interactive e-module. The practicality of the interactive e-module can be measured through a questionnaire on the responses and activities of students. Response questionnaires were given to 20 students who had tried using the interactive e-module. The students' activities were observed by 3 chemistry students through Microsoft Teams. Student response results data are presented in Table 4.

Table 4. Student Response Questionnaire Results

\begin{tabular}{lll}
\hline Criteria & Percentage (\%) & Category \\
\hline Contents & 96 & very responsive \\
Presentation & 98 & very responsive \\
Language & 100 & very responsive \\
Graphics & 100 & very responsive \\
\hline
\end{tabular}

Based on the results of the students' responses, each criterion got a score of more than $81 \%$ which can be categorized as highly responding. It can be stated that the interactive e-module has fulfilled the criteria for practicality (Herawati \& Muhtadi, 2018).

The next step is to test the effectiveness of the interactive e-module by conducting a pretest and posttest with a total of 25 questions. Among them, 10 questions are on the history of the development of the periodic table, 10 questions on the electron configuration 
sub-material, and 5 questions on the quantum number sub-material. The questions given have cognitive dimensions C3 and C4 with a multiple choice question model (Herawati \& Muhtadi, 2018). The pretest is given before students receive the e-module whereas the posttest is given to the students who had used the emodule. The form of posttest is practice questions listed at the end of the material for each sub-chapter. Measurement of student learning outcomes begins with a normality test which aims to determine the distribution of data on the pretest and posttest scores (Hulu \& SInaga, 2019).

Table 5. Normality Test Results

\begin{tabular}{lllllll} 
& \multicolumn{3}{l}{$\begin{array}{l}\text { Kolmogorov- } \\
\text { Smirnov }\end{array}$} & \multicolumn{3}{l}{ Shapiro-Wilk } \\
\cline { 2 - 7 } Pre & Stat & df & Sig. & Stat & df & Sig. \\
\hline Post & .148 & 20 & $.200^{*}$ & .960 & 20 & .537 \\
\hline 165 & 20 & .156 & .963 & 20 & .608 \\
\hline
\end{tabular}

Based on Table 5, it is known that the significant value for the pretest is 0.537 The sig value for the posttest of 0.608 . It can be said that the pretest and posttest values are normally distributed in the Shapiro-Wilk test with a sig value $>0.05$. After knowing the results of the normality test, the t-test can be continued with the aim of knowing the significant difference between the results of the pretest and posttest values presented in Tabel 6 (Hulu \& SInaga, 2019).

Table 6. $\mathrm{t}$ Test

\begin{tabular}{llllllll}
\hline \multicolumn{3}{l}{ Paired Differences } & \multicolumn{1}{l}{ lf } & Sig \\
\hline Mean & Std. & Std. & $95 \%$ & & & & \\
& Dev & Error & Low & Up & & & \\
\hline-36.4 & 12.1 & 2.7 & -42 & -30.7 & -13.4 & 19 & .000 \\
\hline
\end{tabular}

Based on Table 6 the above t-test, it is obtained a significance value (2-tailed) $<0.05 /$ It means that $\mathrm{H} 0$ is rejected and Ha is accepted. H0 stated that there was no significant difference between pretest and posttest. Meanwhile, Ha stated that there was a significant difference between the pretest and posttest. Based on the results of the t-test analysis, the interactive e-module on the elemental periodic system material can be said very effective in improving the quality of online learning (Herawati \& Muhtadi, 2018).

\section{Conclusion}

Based on the results of research and data analysis, it can be concluded that this interactive e-module can be developed by referring to the $4 \mathrm{D}$ research model (Define, Design, Develop, and Disseminate). This interactive e-module can be said to be very feasible in terms of the validity score with each obtaining a score of
90\% for content criteria, $93 \%$ for presentation criteria, $84 \%$ for language criteria, and $100 \%$ for graphic criteria. This interactive E-module is very practical to use, this is evidenced by the results of student responses, each criterion gets a score of $>81 \%$ which can be categorized as highly responding. The interactive e-module also fulfills the effectiveness criteria assessed from the analysis of the t-test results for the increase in score gain, with a significance value (2-tailed) of $0.000<0.05$ (Herawati \& Muhtadi, 2018). Therefore the interactive emodule on the element periodic system material is very effective as a learning medium for online learning activities.

\section{Acknowledgments}

Thank you to all those who have helped the writer to complete the article, especially my parents, the supervisor, and my friends. I hope the article can be used properly by the public and further researchers.

\section{References}

Abidah, A., Hidaayatullaah, H. N., Simamora, R. M., Fehabutar, D., \& Mutakinati, L. (2020). The Impact of Covid-19 to Indonesian Education and Its Relation to the Philosophy of "Merdeka Belajar." Studies in Philosophy of Science and Education, 1(1), 38-49. https://doi.org/10.46627/sipose.v1i1.9

BNSP. (2010). Paradigma Pendidikan Abad XXI. BNSP.

Damayanti, D., \& Dwiningsih, K. (2017). Pengembangan Perangkat Pembelajaran Berorientasi Blended Learning Pada Materi Sistem Periodik Unsur Kelas X SMA. UNESA Journal of Chemistry Education, 6(1), 16-23. [Indonesian]

Depdiknas. (2016). Panduan Pengembangan Bahan Ajar. Direktorat Pembinaan Sekolah Menengah Atas Direktorat Jenderal Manajemen Pendidikan Dasar dan Menengah Departemen Pendidikan Nasional. [Indonesian]

Fausih, M., \& Danang, T. (2015). Pengembangan Media E-Modul Mata Pelajaran Produktif Pokok Bahasan "Instalasi Jaringan Lan (Local Area Network)" Untuk Siswa Kelas Xi Jurusan Teknik Komputer Jaringan Di SMK Negeri 1 Labang Bangkalan Madura. Jurnal UNESA, 01(01), 1-9. https://jurnalmahasiswa.unesa.ac.id/index.php/ jmtp/article/view/10375 [Indonesian]

Herawati, N. S., \& Muhtadi, A. (2018). Pengembangan Modul Elektronik (e-modul) Iinteraktif pada Mata Pelajaran Kimia Kelas XI SMA. Jurnal Inovasi Teknologi Pendidikan, 5(2), 180-191. https://doi.org/10.21831/jitp.v5i2.15424 [Indonesian]

Hulu, V.T., \& SInaga, T. R. (2019). Analisis Data Statistik 
Parametrik Aplikasi SPSS dan Statcal. Yayasan Kita Menulis. [Indonesian]

Izzati, N. (2017). Penerapan Pmr Pada Pembelajaran Matematika Untuk Meningkatkan Kemandirian Belajar Siswa Smp. Jurnal Kiprah, 5(2), 30-49. https://doi.org/10.31629/kiprah.v5i2.283

[Indonesian]

Juilando, F. (2019). Validitas dan Praktikalitas E-Modul Struktur Atom Berbasis Pendekatan Saintifik pada. 3(14). [Indonesian]

Kemendikbud. (2020). Kepmendikbud Nomor 719/P/2020 tentang Pedoman Pelaksanaan Kurikulum pada Satuan Pendidikan dalam Kondisi Khusus pada Pendidikan Dasar dan Menengah. [Indonesian]

Kind, T. Y. E. (2015). Social media for Lifelong Learning. International Review of Psychiatry, 27, 124-132. https://doi.org/10.3109/09540261.2014.990421

Kuntarto, E. (2017). Keefektifan Model Pembelajaran Daring Dalam Perkuliahan Bahasa Indonesia di Perguruan tinggi. Journal Indonesian Language Education and Literature, 3(1), 53-65. http://www.syekhnurjati.ac.id/jurnal/index.php $\angle$ jeill/\%0APEMBELAJARAN [Indonesian]

Ramadhan, S., \& Linda, R. (2020). Pengembangan EModule Interaktif Chemistry Magazine Berbasis Kvisoft Flipbook Maker pada Materi Laju Reaksi Development Of E-Module Interactive Chemistry Magazine Based Kvisoft Flipbook Maker On Reaction Rate Topic. Jurnal Zarah, 8(1), 7-13. [Indonesian]

Rorita, M., \& Saida, U.A.W. (2018). Pengembangan Multimedia Interaktif Berbasis Mobile Learning Pokok Bahasan Perkembangan Teori Atom Mata Pelajaran Kimia Kelas X SMA Panjura Malang No Title. JINOTEP, 70-75. [Indonesian]

Riduwan. (2013). Skala Pengukuran Variabel-Variabel Penelitian. Alfabeta Bandung. [Indonesian]

Sholeh, H. (2017). Pengembangan Kurikulum Baru. PT Remajaa Rosdakarya Bandung. [Indonesian]

Strielkowski, W. (2020). COVID-19 Pandemic and the Digital Revolution in Academia and Higher Education. Preprints, April, 1-6. https://doi.org/10.20944/preprints202004.0290.v $\underline{1}$

Suarsana, I.M., \& Mahayukti, G.A. (2013). Pengembangan E-Modul Berorientasi Pemecahan Masalah untuk Meningkatkan Keterampilan Berpikir Kritis Mahasiswa. Jurnal Nasional Pendidikan Teknik Informatika (JANAPATI), 2(3), 193. https://doi.org/10.23887/janapati.v2i3.9800 [Indonesian]

Syarmadi, \& Izzati, F. (2020). Validitas Modul Elektronik Matematika sebagai Bahan Ajar Berbasis Augmented Reality pada Materi Bangun Ruang Kubus dan Balok Kelas VIII SMP. Student Online
Journal, 1, 674-680. [Indonesian]

Thiagarajan, S. A. O. (1976). Instructional Development for Training Teachers of Exceptional Children: A sourcebook. Journal of School Psychology, 14(1), 75. https://doi.org/10.1016/0022-4405(76)90066-2

Waryanto, B., \& Millafati, Y.A. (2006). Transformasi Data Skala Ordinal ke Interval dengan Menggunakan Makro Minitab. Informatika Pertanian, 15, 881-895. [Indonesian] 